\title{
Przekład i (bez)krytyczna analiza dyskursu
}

\author{
Elżbieta Tabakowska
}

Uniwersytet Jagielloński

elzbieta.tabakowska@gmail.com

\section{Streszczenie}

Celem artykutu jest potwierdzenie tezy, że postulat transdyscyplinarności, wysuwany $w$ rozważaniach dotyczacych współczesnego przekładoznawstwa, znajduje uzasadnienie $w$ zbieżności podstawowych założeń językoznawstwa kognitywnego, krytycznej analizy dyskursu i wiedzy o przektadzie. „Zwrot kulturowy” $w$ przekładoznawstwie, odnotowany $w$ tym samym czasie, co „zwrot kognitywny” w nauce o języku, oznacza możliwość wkroczenia obu dyscyplin na teren praktycznie zarezerwowany dla badań nad krytyczna analiza dyskursu. Przełamanie niechęci lub braku zainteresowania dla sasiednich dyscyplin prowadzi do rozszerzenia wspólnej płaszczyzny działania. Tezę ilustruje studium przypadku: przykład ttumaczenia tekstu, o którego językowym kształcie decyduje szeroki kontekst społeczny $i$ kulturowy.

Słowa kluczowe: językoznawstwo kognitywne, kontekst, krytyczna analiza dyskursu, stereotyp, transdyscyplinarność, „, zwrot kognitywny”, ,zwrot kulturowy”

Abstract

Translation and the (Un-)critical Discourse Analysis

The paper argues that the postulate of transdisciplinarity, put forward by today's TS scholars, is justified by the convergence of basic principles and assumptions which underlie Cognitive Linguistics, Critical Discourse Analysis and Translation Studies. The "cultural turn" in TS occurred at the same time as the "cognitive turn" in linguistics; both make it possible for CL and TS to cross the boundary and enter the area traditionally occupied by CAD. Overcoming the feeling of mutual reluctance or lack of interest in the research carried out within neighbouring disciplines would make it possible to broaden the plane shared by the scholars. As an illustration, a case study is discussed, providing a text whose linguistic shape in translation is influenced by a broad social and cultural context.

Keywords: "cognitive turn", cognitive linguistics, context, stereotype, critical discourse analysis, "cultural turn”, transdisciplinarity 


\section{Wstęp}

We współczesnych badaniach nad przekładem status przekładoznawstwa jako dziedziny interdyscyplinarnej przyjmowany jest jako rzecz oczywista. Badacze podejmują mniej lub bardziej udane próby zasypywania przepaści dzielącej podejście „literaturoznawcze” od ,językoznawczego"- przepaści, którą systematycznie pogłębiano w czasach, gdy literaturoznawcy i językoznawcy działali w myśl założenia, że mniej ich łączy niż dzieli. Zapoczątkowany w latach dziewięćdziesiątych ubiegłego stulecia „zwrot kulturowy” w przekładoznawstwie (Bassnett 1990, 1998) oznaczał odejście od dawnych założeń. Upadły tezy o stabilnym znaczeniu oryginałów i o tradycyjnie pojmowanej ekwiwalencji przekładów. Przekraczając ciasne granice wytyczone przez dwa teksty, albo szerzej, przez systemy dwóch języków, rygorystycznie podporządkowane regułom strukturalizmu, zwolennicy zwrotu kulturowego postulowali włączenie w zakres badań nad przekładem złożonych zjawisk usytuowanych na pograniczach odmiennych kultur. Chodziło już nie tyle o odwzorowywanie znaczeń jednego tekstu w tekście należącym do innego języka, ile o poszukiwanie znaczeń wyłaniających się ze spotkania dwóch kultur. Spotkania, a nie czołowego zderzenia. Trawestując tezę Michała Pawła Markowskiego, dla którego „literatura [jest] opowieścią o innym, który przestaje być obcy" (2014), przekład uznano za dialog z innym, który wprawdzie nie przestaje być inny, ale nie jest obcy.

\section{Przekładoznawstwo, JK, KAD: granice i pogranicza}

Jest rzeczą znamienną, że zwrot kulturowy w przekładoznawstwie nastąpił $w$ niemal dokładnie tym samym czasie, co zwrot kognitywny w językoznawstwie. Podobne też były powody frustracji skłaniające badaczy do schodzenia z przedeptanych ścieżek. Paradygmat strukturalistyczny, który w szczytowej fazie swego rozwoju przyjął kształt gramatyk generatywno-transformacyjnych Noama Chomsky'ego i zwolenników proklamowanego przez niego podejścia do języka i opisów gramatycznych, okazał się dość bezradny w konfrontacji z „czynnikiem ludzkim”. Można było albo ów czynnik ignorować, ograniczając rozważania do badania języka jako abstrakcyjnego wytworu ludzkiego umysłu (włączając się w ten sposób w nurt nazwany „pierwszą rewolucją kognitywną”), albo rozszerzyć pole badawcze, wprowadzając w obszar badań złożone uwarunkowania procesów poznawczych (i spełniając w ten sposób postulaty „drugiej rewolucji kognitywnej”). Pierwsze stanowisko oznaczało utrzymanie tez o autonomii języka i możliwości stworzenia obiektywnego opisu 
semantycznego, abstrahującego od indywidualnych różnic na poziomie różnych grup społecznych lub jednostek. Podejście drugie prowadziło do utożsamienia znaczenia z konceptualizacją - kreowaniem struktur pojęciowych w procesie przetwarzania informacji, z wykorzystaniem wiedzy człowieka o otaczającym go świecie. Badanie języka stało się już nie tylko badaniem zdolności ludzkiego umysłu, ale analizą zachodzących w umysłach ludzi rzeczywistych procesów poznawczych, rozpatrywanych w szeroko zakreślonych kontekstach społecznych i kulturowych. Ceną za to zbliżenie do prawdy była rezygnacja z oszczędnej elegancji opisu, a warunkiem koniecznym - językoznawczy „zwrot kulturowy”. Podobnie jak w przypadku przekładoznawstwa, wymogiem uprawiania językoznawstwa stało się przekraczanie granic macierzystej dyscypliny.

W efekcie takiej zmiany paradygmatu językoznawstwo kognitywne (JK) weszło w skład rozwijającej się dynamicznie dziedziny nauk kognitywnych, obok psychologii poznawczej, neurobiologii i sztucznej inteligencji. Za podstawową zasadę współdziałania poszczególnych dyscyplin uznano interdyscyplinarność, którą dziś coraz powszechniej zastępuje postulat transdyscyplinarności. W odróżnieniu od interdyscyplinarności, która zezwala na przekraczanie granic, uznając jednocześnie priorytet dyscypliny uważanej przez daną grupę badaczy za „główną” (w odróżnieniu od dyscyplin „pomocniczych”), transdyscyplinarność zachowuje autonomię dyscyplin, wszystkim przyznając równy status; oznacza ,jednoczenie nauki ponad dyscyplinami” (Nicolescu 2002). Hołdując tej zasadzie, współczesne językoznawstwo szuka zarówno potwierdzenia jak i rozszerzenia własnych tez na obrzeżach innych dyscyplin tworzących sieć wiedzy o świecie. Warto zauważyć, że analogiczny postulat wysunął ponad ćwierć wieku temu jeden $\mathrm{z}$ twórców kognitywnego paradygmatu W językoznawstwie, George Lakoff, nazywając go „zobowiązaniem do kognitywizmu” (Lakoff 1989).

Współczesne przekładoznawstwo dostrzega oczywiście potrzebę transdyscyplinarności. Uznany kontekst badań nad przekładem stanowią dziś filozofia i antropologia, podobnie jak studia postkolonialne czy gender studies (por. np. Heydel, Bończa de Bukowski 2015). Od kilkunastu lat często pojawia się postulat szerszego wplecenia w transdyscyplinarną sieć dwóch istotnych węzłów: językoznawstwa - szczególnie paradygmatu opatrzonego nieprecyzyjną (lecz powszechnie używaną) etykietą ,językoznawstwa kognitywnego" (JK) oraz analizy dyskursu - a szczególnie podejścia znanego jako krytyczna analiza dyskursu (KAD).

Jako dziedzina transdyscyplinarna par excellence, KAD sytuuje się na pograniczu nauk humanistycznych i społecznych, a ściślej językoznawstwa i socjologii; skupiając się na 
badaniu językowego wymiaru zjawisk społecznych, analizuje ,społeczny kontekst <języka w użyciu> i jego relacje z rzeczywistością społeczną” (Warzecha 2014: 164). Zwięzłą definicję przedmiotu KAD stanowi tytuł kanonicznej monografii wydanej pod wspólną redakcją uważanego za twórcę KAD językoznawcy brytyjskiego Normana Fairclougha i propagatorki KAD na gruncie polskim, Anny Duszak: „Krytyczna analiza dyskursu: interdyscyplinarne podejście do komunikacji społecznej” (Duszak i Fairclough 2008). Przyjmując tę definicję, wypada uznać, że KAD jest od dawna przedmiotem zainteresowania także polskich językoznawców, którzy - nie potwierdzając expressis verbis tej afiliacji - włączają się w dyskusję nad ,językowym wymiarem zjawisk społecznych”. W tym nurcie sytuują się, na przykład, prace Walerego Pisarka (retoryka dziennikarska, komunikacja społeczna), Jerzego Bralczyka (język propagandy i polityki), Katarzyny Kłosińskiej (polskie dyskursy polityczne po 1989 roku), czy Michała Rusinka (,retoryka podręczna”).

W badaniach dyskursu można wyróżnić, za Teunem van Dijkiem, trzy główne wymiary: językowy, komunikacyjny i kulturowy (van Dijk 2001). Pierwszy dotyczy organizacji wypowiedzi językowej, drugi - przekazu funkcjonującego w społecznym obiegu, trzeci znaczeń uwarunkowanych określoną formacją kulturową. Realizując ten program, badacze poszukują „norm, czy - szerzej - istniejących w języku ram interpretacyjnych świata” (Biskupska 2014: 370 ), zbliżając się tym samym do językoznawczych badań nad językowym obrazem świata. Rosnące zainteresowanie nauk humanistycznych związkami między językiem, kulturą i kontekstem społecznym - wspólne, jak się wkrótce okazało, dla językoznawstwa i analizy dyskursu - przyniosło kolejny zwrot, nazwany „zwrotem lingwistycznym".

Zainteresowanie badaczy dyskursu osiągnięciami językoznawstwa nie oznaczało jednak rezygnacji z odrębności ich dyscypliny. Przedmiotem analizy dyskursu - a analizy KAD w szczególności - są wprawdzie teksty, ale definicja tekstu odbiega w istotny sposób od przyjętej w (przed-kognitywnym) językoznawstwie. Dla językoznawców tekst jest linearnym przekazem werbalnym, należącym do określonego gatunku, mającym określoną strukturę i spełniającym określoną funkcję. Badacz dyskursu natomiast definiuje go jako przejaw określonych interaktywnych zachowań społecznych; według klasycznej definicji zaproponowanej przez jedną z prekursorek KAD, Ruth Wodak, tekst jest „konkretną, unikatową realizacją dyskursu" (Ruth Wodak 2011: 18, za Kopińska 2016: 323). Dyskurs bada się w określonym kontekście, definiowanym na różnych poziomach (por. Kopińska 2016: 317-318). Poziom pierwszy stanowi kontekst językowy, ale językowej analizie towarzyszą pytania wykraczające poza tradycyjne językoznawstwo - na przykład pytanie o 
wiedzę i tożsamość twórcy przekazu. Drugi poziom dotyczy aspektu intertekstualnego: związku badanego tekstu $\mathrm{z}$ innymi tekstami, powstającymi w ramach określonej formacji kulturowej. Poziom trzeci oznacza wyjście poza konkretny dyskurs i porównanie określonego przedmiotu badań z innymi dyskursami, dokonywane $\mathrm{w}$ oparciu o przyjęte kryteria (np. tematyka lub źródło, z którego pochodzi badany materiał). Ostatecznym celem jest umieszczenie wyników analiz w kontekście społecznym, politycznym i historycznym, „w którym działania dyskursywne mają miejsce” (Wodak 2001: 67, za Kopińska 2016: 318); temu celowi służy analiza prowadzona na najwyższym, czwartym poziomie.

Rolę językoznawstwa podkreśla się na ogół przede wszystkim w odniesieniu do bezpośredniego, językowego „kontekstu pierwszego poziomu” (por. np. Kopińska 2016; Biskupska 2014). O ile jest to podejście uzasadnione w odniesieniu do paradygmatu językoznawstwa strukturalistycznego, o tyle teoria języka powstała w wyniku drugiej rewolucji kognitywnej zaprasza do transdyscyplinarności. Paralele między analizami przekazów werbalnych prowadzonych w ramach KAD i w ramach JK są bowiem oczywiste.

Podobnie jak KAD, JK zakłada, że przekaz werbalny, z konieczności linearny, powstaje w warunkującym go kontekście „pięciu wh” (od angielskich zaimków who („kto”), to whom („do kogo”), where („gdzie”), when („kiedy”) i why (,po co/dlaczego”)), a o jego znaczeniu decyduje połączenie treści z językowym kształtem wypowiedzi. Podstawowe hasło JK brzmi: „gramatyka ma charakter symboliczny”. Ponadto, podkreślanie roli kontekstu pociąga za sobą wymóg odwoływania się do „wiedzy tła”. Postulat negocjowania znaczeń - stanowiący podstawę fundamentalnego procesu poznawczego, definiowanego $\mathrm{w}$ JK jako proces integracji pojęciowej (por. np. Libura 2010) - zakłada analizowanie tekstu także jako przejaw interakcji, a leżąca u podstaw kognitywistycznej myśli o języku zasada kreacjonizmu odpowiada przyjmowanemu w KAD założeniu, że dyskurs jest nie tylko nieodłącznym elementem świata społecznego, istotnym dla jego zrozumienia, ale także ten świat kreuje, jest bowiem siłą sprawczą w interakcjach społecznych (Duszak, Fairclough 2008: 15-16).

O roli, jaką JK ma do odegrania we współczesnych rozważaniach przekładoznawczych, napisano już stosunkowo wiele, także w Polsce (por. np. prace Krzysztofa Hejwowskiego, Mikołaja Deckerta, Agnieszki Gicali czy Elżbiety Tabakowskiej), natomiast KAD nie jest w polskiej literaturze przedmiotu zbyt często obecna. W literaturze anglojęzycznej poza nielicznymi wyjątkami (np. Shahbazi, Rezaee (2017) wykorzystujący KAD do analizy Chaty Wuja Toma Beecher Stowe), badania skupiają się na przekazach medialnych i prasowych (por. np. Schäffner 2004; Ietcu-Fairclough 2008). W jednej z nowszych prac omawiających wkład analizy dyskursu w badania nad przekładem autorzy stwierdzają, że „podejście [wypracowane 
w ramach] analizy dyskursu zostało nieco zmarginalizowane przez nowe kierunki w przekładoznawstwie, zainspirowane badaniami z dziedziny kognitywizmu i socjologii” (Zhang, Munday 2018: 159, thum. i podkr. E.T.). Ten „margines” jest jednak bardzo szeroki, ponieważ łatwo dostrzec obszary wspólne dla wszystkich trzech dyscyplin.

Nie wchodząc w powszechnie znane szczegóły, warto w tym miejscu zauważyć, że przesunięcie akcentu z przekładu rozumianego jako produkt na przekład rozważany jako proces oznacza oczywiste uwzględnianie czynników właściwych analizie dyskursu. Podkreślenie roli procesów decyzyjnych thumacza jako jednostki funkcjonującej w określonym czasie i miejscu oraz usytuowanie procesu przekładu w określonym kontekście społecznym i kulturowym oznacza kres „mitu przezroczystej szyby”. Tłumacz ma przed sobą tekst, konkretną, niepowtarzalną realizację dyskursu, który był kiedyś dyskursem Innego. Teraz musi ten dyskurs na nowo stworzyć, mając świadomość jego inności, a potem dokonać własnej konkretnej i niepowtarzalnej realizacji, czyli stworzyć nowy dyskurs, który będzie - z definicji - inny. Tłumacz nie może więc pozostać niewidoczny, ponieważ to jest jego „autorska” realizacja i to on ostatecznie decyduje o kształcie przekazu powstającego jako efekt przekładu. To jego przywilej i jego odpowiedzialność. Jak uczy KAD, tłumacz staje się uczestnikiem procesu komunikacji społecznej. Tekst oryginału i tekst przekładu należą do dwóch różnych dyskursów, które prowadzą ze sobą swoisty dialog; każdemu $\mathrm{z}$ nich przysługuje Bachtinowska dialogiczność i każdy jest Bachtinowskim „cudzym słowem”. Każdy odwołuje do wcześniejszych kontekstów, stwarzając napięcie między interpretacją i zachowaniem autonomii tego, co „cudze”, a prawem tłumacza do zachowania własnej tożsamości.

$\mathrm{W}$ ostatecznym rozrachunku, na transdyscyplinarnym pograniczu JK, KAD i nauka o przekładzie odnajdują wspólne zasady działania (pierwotnie sformułowane dla badań z zakresu analizy dyskursu): „traktowanie języka zarówno jako społecznie konstruowanego, jak i konstruującego; uznanie, że to samo zjawisko może być relacjonowane na wiele różnych (i różniących się między sobą) sposobów; przyjęcie, że nie ma jednego niezawodnego sposobu postępowania z różnorodnością relacji - niepodobna powiedzieć, które są literalne, a które „retorycznie wprowadzające w błąd” - i że centralnym tematem badań powinny być „zmienne i twórcze sposoby użycia języka” (Potter, Wetherell 1987: 35, za: Biskupska 2014: 381). Kiedy Jonathan Potter (psycholog społeczny) i Margaret Wetherell (badaczka dyskursu) pisali te słowa, miały one nieco inną wymowę niż dziś. Autonomiczne językoznawstwo w wydaniu teorii transformacyjno-generatywnej, podobnie jak przekładoznawstwo sprzed zwrotu kulturowego, uznałyby zapewne, że żadna z tych zasad nie dotyczy nauki o języku; dziś 
postulat analizowania struktur językowych w kontekście interakcji społecznej wydaje się oczywistością. Warto pamiętać, że w tym samym roku, w którym Potter i Wetherell opublikowali swoją monografię, twórca modelu gramatyki kognitywnej, amerykąński językoznawca Ronald W. Langacker, wydał swój językoznawczy manifest (Langacker 1987). Dwa lata wcześniej Fairclough przedstawił cele KAD (Fairclough 1985).

W kolejnych dekadach JK i KAD podejmowały zadania wyznaczone przez brytyjskiego lingwistę Rogera Fowlera dla propagowanej przez niego gałęzi językoznawstwa, której nadał nazwę „krytycznej lingwistyki”. Ćwierć wieku temu Fowler pisał: „krytyczna lingwistyka opiera się na założeniu, że każda reprezentacja jest zapośredniczona i ukształtowana przez systemy wartości zakorzenione w medium wykorzystywanym w tej reprezentacji. (...) To nie jest język w tym znaczeniu, w jakim go rozumie tradycyjne językoznawstwo. Krytyczna lingwistyka to językoznawstwo <instrumentalne>, wykraczające poza formalne struktury abstrakcyjnego systemu i zmierzające $\mathrm{w}$ stronę praktycznej interakcji między językiem i kontekstem" (Fowler 2003: 4, 9, tłum. - ET). Takie założenie leży także u podstaw współczesnej nauki o przekładzie.

\section{Studium przypadku}

Jako ilustrację powyższych rozważań, przedstawię los polskiego przekładu biograficznej opowieści Ireny Powell zatytułowanej The Daughter Who Sold Her Mother. A Biographical Memoir (tytuł polski „Córka, która sprzedała matkę”). Tematem opowieści są wojenne i powojenne losy polskiej Żydówki, Sary Rubinstein vel Julii Janickiej, i jej córki, brytyjskiej japonistki z Uniwersytetu w Oksfordzie, Ireny Powell née Janickiej. Żywa narracja wciąga czytelnika, a pospieszna lektura może stwarzać wrażenie, że ma się do czynienia z kolejną pozycją na długiej liście narracji określanych mianem „literatury Holocaustu”.

Książka jest napisana prostym językiem, typowym dla osobistych rodzinnych wspomnień. Zapowiedzią translatorskich problemów stają się więc dopiero jej konteksty. Najbardziej oczywisty (i najłatwiejszy do opisania) jest kontekst językowy. Ojczystym językiem córki jest język polski, i w tym języku Irena zawsze rozmawiała z matką, natomiast Sara - urodzona i wychowana w galicyjskim sztetlu - miała w młodości ukraińskich przyjaciół i chodziła do ukraińskiej szkoły, a w jej rodzinnym domu na co dzień mówiło się w jidysz. Podczas niemieckiej okupacji ukrywała się we wsi na południu Polski, a po wojnie przez długi czas mieszkała i pracowała w Polsce. Języka polskiego przez wiele lat używała w domu i poza domem. Obie bohaterki znały też język hebrajski - matka ze słynnego krakowskiego 
Hebrajskiego Gimnazjum, córka $-\mathrm{z}$ kontaktów $\mathrm{z}$ rodziną $\mathrm{i}$ przyjaciółmi $\mathrm{z}$ Izraela. Wspomnienia matki obejmują językowe kontakty z okupantem (niemiecki) i zwycięzcami (rosyjski); językiem córki, po wyjeździe do Wielkiej Brytanii, stał się język angielski.

Za wyjątkiem angielskiego, wszystkie te języki podpowiadają polskiemu czytelnikowi kulturowe i społeczne konteksty, nierzadko niejednoznaczne aksjologicznie (np. język ukraiński w kontekście II wojny światowej i dzisiejszej imigracji Ukraińców do Polski; język niemiecki w odczuciu Polaków należących do różnych pokoleń, język rosyjski w różnych rejonach Polski i w różnych okresach powojennej historii kraju). Mogłoby się wydawać, że język polski - język omawianego w tym eseju przekładu - będzie wolny od aksjologicznych obciążeń, ale sprawa nie jest oczywista. Jak powiedzieliśmy, autorka biografii rozmawia z matką po polsku, w języku, którego bardzo dobrą znajomość Sara zachowała do końca życia. Ale pod wpływem emocji, poruszona wydarzeniami z marca 1968, wraca do ,językowych korzeni":

(1) „Przeze mnie Polski może nie być!” (Powell 510)

i ubiera polskie słowa w składnię języka jidysz. ${ }^{1}$ Po polsku powiedzielibyśmy „Jak dla mnie...”, Jeśli idzie o mnie..." Oryginał zachowuje kształt tego okrzyku, w polskim przekładzie sygnał ginie i rodzi się podejrzenie, że tłumacz po prostu popełnił błąd gramatyczny.

Irena Powell pisała książkę z myślą o swoich anglojęzycznych synach, którym chciałaby przybliżyć ich „polską Babcię”. Pisze więc po angielsku, ze świadomością, że musi stworzyć tekst, który będzie dostępny brytyjskim wnukom Sary. Powstaje narracja będąca przekładem polskich rozmów z matką; w odbiorze synów Ireny tekst nieuchronnie „obrośnie” kontekstem kultury, której przedstawiciele nie mają za sobą doświadczeń choćby trochę podobnych do tych, jakie były udziałem dwóch polskich Żydówek. Autorka steruje więc tym potencjalnym dyskursem, a świadomy swoich obowiązków tłumacz musi sobie zadawać pytanie, czy te „stery” nie poprowadzą polskiego czytelnika niewłaściwym kursem.

Oczywistym intertekstualnym aspektem opowieści Sary i Ireny jest fakt, że ze względu na czas i miejsce akcji książka wpisuje się w nurt „literatury Holokaustu”. Będzie czytana w relacji do wielu innych tematycznie i gatunkowo zbliżonych narracji. Ale to nie jest typowa „książka o Zagładzie”. Jest przede wszystkim opowieścią o złożonych relacjach między matką

\footnotetext{
${ }^{1}$ Silna emocja często wyraża się w języku „najbardziej ojczystym” - to fascynujący temat; na jego szersze omówienie nie ma tu jednak miejsca.
} 
i córką, kształtowanych $\mathrm{w}$ wyniku ich traumatycznych przeżyć. Ale jest także złożoną opowieścią o roli stereotypów $\mathrm{w}$ myśleniu i działaniu - bohaterek i autorki, ale także tłumaczki i czytelników jej przekładu. Jest opowieścią o umacnianiu i przełamywaniu stereotypów, o ich dynamice i złożonych uwarunkowaniach.

Jak wiadomo, badania podejmowane w ramach KAD koncentrują się - niejako z definicji - na tematach zapalnych (hot topics), osiągających wysokie temperatury w określonych miejscach i w określonym czasie. W kanonicznym wprowadzeniu do KAD (van Dijk 2015) na tej liście znalazły się etnocentryzm, antysemityzm, nacjonalizm i rasizm. Książka Powell wpisuje się w kontekst, w którym wiele z panujących w komunikacji społecznej dyskursów przywołuje nie tylko takie postawy, ale także utrwalone w myśleniu ludzi stereotypy i związane z tymi stereotypami emocje. W takim kontekście funkcjonuje zarówno tłumacz, jak i jego czytelnicy. Ramy niniejszego eseju nie pozwalają na głębsze teoretyczne omówienie tych zależności, ponieważ wymagałoby to szerszej wiedzy i obszernych odwołań do literatury z dziedziny socjologii i psychologii społecznej. Niektóre istotne problemy zostaną więc z konieczności potraktowane pobieżnie i jednowymiarowo, co oczywiście pociąga za sobą niebezpieczeństwo dużych - i często zbyt radykalnych - uproszczeń. ${ }^{2}$

Stereotypy - podobnie jak leżące u ich podstaw hot topics KAD - znajdują wyraz w „języku rozmów, obiegowych opowieści, doniesień medialnych, podręczników, parlamentarnych debat, wiadomości prasowych, dyskursu korporacyjnego, konferencji i prac naukowych" (van Dijk 2015: 476, tłum. ET). Są przekazywane za pośrednictwem języka lub przez język przywoływane z magazynów „wiedzy tła”. Muszą więc interesować tłumacza proporcjonalnie do roli, jaką odgrywają w przekładanym tekście.

W roku, w którym w Wielkiej Brytanii ukazał się oryginał książki Powell (2016), za istotne tło decyzji podejmowanych przez jej tłumacza można było uznać dwa stereotypy etniczne dotyczące dwóch narodów i ich wzajemnych skomplikowanych i bolesnych relacji. W wielkim uproszczeniu, Żydzi w oczach części Polaków jawili się jako fanatycy religijni i innowiercy (z istotnym elementem streszczającym się w formule „Żydzi wydali i zabili Pana Jezusa") oraz jako syjoniści (oceniani negatywnie za rzekomy skrajny nacjonalizm, przejawiający się wrogością wobec Polaków). Natomiast hołdujący stereotypom Polacy często widzieli samych siebie jako „Polaków-katolików”, w większości popełniających w czasie II wojny światowej czyny, za które należałoby ich nagradzać drzewkami w Yad Vashem. Zaledwie cztery lata później, czyli w roku wydania polskiego przekładu książki (2020), te

\footnotetext{
${ }^{2}$ Wydaje się, że szczególnie pomocne byłoby w tym kontekście odwołanie się do psychologicznej teorii oceny, która wiąże ocenę zachodzących w życiu ludzi zdarzeń z ich reakcjami emocjonalnymi.
} 
stereotypy przedstawiały się już nieco inaczej. Pozytywny stereotyp Polaka - w oczach Polaków - nie uległ wprawdzie zasadniczej zmianie, ale antysemicki stereotyp Żyda był już znacząco inny ${ }^{3}$.

Zderzenie obu Sara widzi tak:

(2)EN. "What did the Poles have against us? (...) How many [Jews] , do you think, were left after the war?", she asks, only to provide her own answer, "A handful". And after a short pause she adds contemptuously, "But even that was too much for them. What a nation!" (...)..."it is twice by now that Poles have benefitted materially from Jewish misery, at least twice (...), once under Hitler, when Jews were herded into the ghettos and had to leave all their possessions behind, and the second time again in 1968 !”

(Powell 511, 526, podkr. E. T.)

PL. - Co Polacy mieli przeciwko nam? (...) Twoim zdaniem jak wielu w ogóle ich zostało po wojnie? - pyta i zaraz sama sobie odpowiada: - Garstka. A po krótkiej chwili dodaje pogardliwym tonem: Ale dla nich nawet to było zbyt wiele. Co za naród! (...) ...do dziś Polacy już dwa razy odnieśli materialne korzyści z nieszczęścia Żydów - co najmniej dwa razy (...) raz za Hitlera, kiedy Żydów zapędzono do gett i kiedy musieli porzucić całe swoje mienie, i drugi raz w 1968 roku!"

(Powell/Tabakowska 661, 681-682, podkr. E. T.)

Analizy porównawcze oryginałów i przekładów skupiają się na ogół na semantyce leksykalnej; przedmiotem porównania jest wówczas proces decyzyjny tłumacza, nazywany potocznie „doborem słów”. Ale istotna jest także gramatyka, której JK przyznaje zdolność „symbolizowania treści” (por. Langacker 1987, 2009). W (2) EN i (2) PL badacz hołdujący zasadom krytycznej lingwistyki powinien się skupić na trzech zjawiskach gramatycznych: rodzajniku, akcencie zdaniowym i strukturze frazy rzeczownikowej. W (2)EN korzyści materialne podnosili wszyscy Polacy (Poles), ale tylko niektórzy (the Poles) byli wrogami Żydów. I to tylko ci niektórzy (w oryginale zaznaczeni kursywą, oddającą akcent w mówionym tekście: them) odpowiadali za wydarzenia 1968 roku. W (2) PL natomiast kwestia pozostaje nierozstrzygnięta. Ponadto, fraza „nieszczęście Żydów” (w nomenklaturze JK "konstrukcja punktu odniesienia”) określa nieszczęście jako coś, co stało się udziałem Żydów. Natomiast w (2) EN to nie jest misery of the Jews, lecz Jewish misery - powstaje w ten sposób

\footnotetext{
${ }^{3}$ Nasilenie antysemickich nastrojów i napięcia w stosunkach między III RP i Izraelem nastąpiło, na przykład, w wyniku wprowadzenia i losów niesławnej nowelizacji ustawy o Instytucie Pamięci Narodowej z lipca 2018 roku.
} 
kategoria pojęciowa o wymiarze ogólnym. Zmiany gramatyczne są z pozoru niewielkie, ale skutkują zmianą obrazu Polski i Polaków w oczach Sary.

Opowiadając o ucieczce z ulicznej łapanki, Sara mówi Irenie:

(3) EN “(...) Jasio would help. (...) just about the only genuine Pole - a non-Jew - in our group (...) He mumbled something about not being able to afford to raise any further suspicions".

(Powell 204, podkr. E.T.)

PL „Jasio na pewno pomoże. (...) chyba jedyny prawdziwy Polak - aryjczyk ${ }^{4}-\mathrm{w}$ naszej grupie. (...) - wymruczał coś, że niby nie może sobie pozwolić na to, żeby wzbudzać dodatkowe podejrzenia.

(Powell/Tabakowska 280-281, podkr. E.T.)

"Chyba jedyny prawdziwy Polak" - w ustach narratorki to mógłby być komplement, ale okazuje się, że Jasio stchórzył. „Wymruczał coś” - czy przestraszonej Sarze było go trudno zrozumieć, czy też może nie miał odwagi jasno i wyraźnie odmówić Sarze schronienia? Złożona składnia drugiej części zdania jest ikonicznym odwzorowaniem plątaniny słów w gorączkowym poszukiwaniu sensownej wymówki. Dobrze, że syntaktyczna zawiłość pojawiła się również w przekładzie. Natomiast podczas gdy w oryginale Jasio po prostu nie jest Żydem, w przekładzie jest aryjczykiem. To znacząca afirmacja. Różnica jest niewielka, ale wpisująca się w społeczny i kulturowy kontekst.

Polski przekład książki Ireny Powell ukazał się na polskim rynku w bardzo szczególnym momencie. W 2018 roku Sejm uchwalił nowelizację ustawy IPN o odpowiedzialności lub współodpowiedzialności za zbrodnie popełnione przez III Rzeszę Niemiecką. Ustawa wywołała krytykę w wielu krajach i spowodowała napięcie w stosunkach między Polską a USA i Izraelem. Ambasador Izraela Anna Azari zaapelowała o zmianę nowelizacji, argumentując, że ustawę można potraktować ,jak możliwość kary za świadectwo ocalałych z Zagłady". W efekcie szybko wprowadzono poprawki, co jednak nie usunęło napięć, umacniając oficjalną tezę o pozycji Polski jako „największej ofiary nazistowskich zbrodni” i podsycając odradzające się w kraju antysemickie nastroje. W lipcu 2020 roku rzecznik praw obywatelskich Adam Bodnar stwierdził w jednym z wystąpień: ,antysemickie wypowiedzi coraz częściej pojawiają się w dyskursie medialnym, także głównego nurtu” (Bodnar 2020).

\footnotetext{
${ }^{4}$ Tak w opublikowanej wersji przekładu, którą dziś uznałabym z błędną; Sara użyłaby określenia „goj” (tę spóźnioną uwagę zawdzięczam jednemu z moich anonimowych PT Recenzentów).
} 
Można w tym miejscu przytoczyć językowe konteksty obchodów 75. rocznicy wyzwolenia obozu w Auschwitz z pamiętnym przemówieniem byłego więźnia Auschwitz, dziennikarza Mariana Turskiego. „Nie bądź obojętny”, wzywał Turski. „Bo jeżeli będziesz, to nawet się nie obejrzycie, jak na was, na waszych potomków jakieś Auschwitz nagle spadnie z nieba" (Turski 2020).

W następnym roku w zainicjowany przez IPN dyskurs wpisał się proces wytoczony Barbarze Engelking i Janowi Grabowskiemu, autorom dwutomowego opracowania Dalej jest noc. Zarzucając wybitnym historykom „nienawiść do Polski i Polaków”, podważono treść jednego z licznych przypisów, opierając zarzut na fragmentarycznych zeznaniach świadków wydarzeń i ich rodzin. W tym samym czasie parlamentarny zespół pod kierownictwem posła PiS Arkadiusza Mularczyka przygotowywał raport w sprawie reparacji dla Polski od Niemiec za zniszczenia podczas II wojny światowej. Zakończona z końcem 2020 roku niemiecka prezydencja w Unii Europejskiej oznaczała wzbogacenie dyskursu na temat reparacji o dodatkowy ważny wątek.

Mąż Sary i ona sama znaleźli pod koniec życia bezpieczną i dostatnią przystań w niemieckim Frankfurcie. Czy - znów wobec tez JK - przekład partii książki dotyczących pobytu Sary i Romka Janickich w Niemczech mógłby zależeć od identyfikacji thumacza z takim czy innym politycznym dyskursem? Odwołajmy się do kolejnego przykładu:

(4) EN: [My father] had strongly encouraged her to come, as there was, he suggested, a chance for German reparations, which would give them means of support. (...) There is an inescapable irony in the fact that, in his final years, it was Germany where my father found work and security (...) Naturally, no one there knew or was interested in his previous life. (...) he was fortunate enough to find employment [and] derived a small amount of pleasure and satisfaction from the fact that, despite his age and despite the - to him - foreign cultural environment in which he now had to function, his work met with genuine appreciation from his new colleagues.

(Powell 525, 535, podkr. E. T.)

PL: W listach gorąco ją zachęcał do przyjazdu, ponieważ, jak twierdzil, była szansa na uzyskanie niemieckich reparacji, co by im zapewniło środki utrzymania. (...) Gorzka ironia kryje się w fakcie, że w ostatnich latach życia właśnie w Niemczech mój ojciec nalazł pracę i poczucie bezpieczeństwa (...) Oczywiście nikt tam nie wiedział ani też nie czuł potrzeby, żeby się dowiedzieć, jak wcześniej wyglądało jego życie. (...) Wystarczało mu, że znalazł pracę [i] czerpał pewną przyjemność i satysfakcję z faktu, że pomimo wieku i pomimo obcości - z jego 
punktu widzenia - środowiska kulturowego, w jakim teraz musiał funkcjonować, jego praca cieszyła się szczerym uznaniem nowych kolegów.

(Tabakowska/Powell 680, 693, podkr. E.T.).

Warto się przyjrzeć polskiemu przekładowi. „Niemieckie reparacje” - w odróżnieniu od, na przykład, „odszkodowania od Niemców” - ze sporym prawdopodobieństwem przywołają kontekst wspomnianej wyżej politycznej akcji polskich parlamentarzystów. W przypadku Żydów przyjeżdżających do Niemiec szanse na uzyskanie reparacji stają się kwestią przekonania („twierdził”), a nie tylko przypuszczeń (suggested). Ironię, od której w oryginale „nie dało się uciec” (komu? Sarze? Irenie? Ojcu Ireny? Czytelnikowi?), w przekładzie opisuje przymiotnik „gorzka” - konwencjonalny element związku frazeologicznego. Niemców nie tyle nie interesuje przeszłość ojca Ireny, co „nie widzą potrzeby”, żeby się czegoś o nim dowiedzieć. A on sam nie uważa, że miał szczęście, ponieważ znalazł pracę; nową sytuację uważa po prostu za wystarczająco dobrą. Reasumując, Niemcy wypłacają ofiarom Holokaustu reparacje, ale nie czują potrzeby zainteresowania się nimi, choć doceniają tych ludzi, jeśli dobrze pracują. Natomiast nowi obywatele Niemiec dostrzegają konieczność adaptacji do zastanych tam warunków i uważają swoją sytuację za wystarczającą. Zza tekstu mruga na polskiego czytelnika potoczny stereotyp Niemca: zdyscyplinowany i praworządny, ale pozbawiony empatii, nie okazujący uczuć. W sumie (4) PL podważa jednak stereotyp „złego Niemca", a to rola istotna w świetle dyskursu społecznego pojawiającego się w dzisiejszej Polsce. I jeszcze gramatyka. Struktura zdania It was Germany where... także przywołuje szerszy kontekst narracji: Janiccy znaleźli przystań nie w jakimś innym kraju (ona nie w Izraelu, gdzie jak się dowiadujemy nie mogła się odnaleźć, on nie w USA, które jak pisze córka, nie spełniły jego oczekiwań), ale właśnie w Niemczech, w kraju i wśród narodu, z którym wiąże się ich trauma. Przekład oddaje te asocjacje.

Narracja Powell podważa także dawny polski stereotyp ,złego Ukraińca”, wynikły z historycznych uwarunkowań (Wołyń, akcja „Wisła”). Dziś oczywiście stereotyp ten ulega w Polsce zmianie, od czasu „pomarańczowej rewolucji” i chyba głównie za sprawą bezpośrednich kontaktów przedstawicieli obu narodowości (por. Jurek 2019). W książce Powell Ukraińcy są po prostu dobrzy. Sara i mała Irenka przeżyły, ponieważ nieznajoma młoda Ukrainka oddała Sarze swoje dokumenty:

(5) EN. [I] record the circumstances under which a Ukrainian girl (...) in unheard of generosity of spirit, passed on her own identity document to my mother. (...) For someone like my mother, 
and many others in her situation, this document bestowed nothing less than the right to exist. It was a passport to life.

(Powell 208-209, podkr. E.T.)

PL....notuję sobie okoliczności, w jakich pewna młoda Ukrainka (...) w akcie niesłychanej szczodrości, oddała mojej matce własny dokument tożsamości. (...) ... dla kogoś takiego jak moja matka - i wielu innych w podobnej sytuacji - ten dokument oznaczał ni mniej, ni więcej tylko prawo do istnienia. Był paszportem do życia.

(Tabakowska/Powell 283, 286, podkr. E.T.)

W (5) PL jednostkowość aktu ukraińskiej dziewczyny usprawiedliwia wątpliwości Sary, która mówi córce, że nie mogła uwierzyć, iż Ukrainka nie będzie się domagać gratyfikacji. Ale w oryginale jest mowa o szlachetności ducha, wielkoduszności, która jest stałą cechą charakteru. To drobna gramatyczna różnica - opozycja między policzalnością i niepoliczalnościa, dobrze znana ze szkolnych podręczników do gramatyki. Odarka Wons po prostu jest dobrym człowiekiem, podobnie jak inni Ukraińcy, których Sara spotykała podczas swoich wojennych peregrynacji.

Jeśli polski czytelnik, któremu trudno porzucić stereotypowe myślenie, doświadcza dysonansu poznawczego w wyniku ,złych” i „dobrych” stereotypów, to poczucie dyskomfortu będzie jeszcze większe, jeśli zderzą się ze sobą schematy poznawcze obciążone dużym ładunkiem emocjonalnym. Sara kontestuje stereotyp Polaka głównie w odniesieniu do elementów określanych zbitką „Polak-katolik”; jej reakcje są silnie nacechowane emocjonalnie i można się spodziewać, że wywołają równie silną reakcję u polskich czytelników, choć będzie to reakcja odwrotnie nacechowana aksjologicznie. Pełna oburzenia na wiejskiego księdza, który odmówił udzielenia ślubu matce nieślubnego dziecka, Sara podziwia odwagę „komunisty, wydalonego z Francji po wybuchu wojny”, który ostro zaprotestował - ku oburzeniu innych mieszkańców wsi:

(6) EN ,What's wrong with marrying the girl in a proper fashion? Wasn't the Holy Mother herself a whore?"

(Powell 281, kursywa w oryginale) 
PL: Co byłoby złego, gdyby tej dziewczynie udzielić porządnego ślubu? Czyż sama Matka Boska nie była dziwką???"5

(Tabakowska/Powell 376)

W przekładzie nie pojawił się odpowiednik dosadnego wulgaryzmu, a i tak wobec cechującego polski katolicyzm kultu maryjnego ostatecznie wybrana przez thumacza złagodzona wersja może się okazać kontrowersyjna. Podobnie zresztą jak opór Sary przed przyjęciem wizyty chodzącego „po kolędzie” miejscowego księdza:

(7) EN. „But it is not always easy to keep away from the priest”. On the days he was making his rounds on her side of the village, she would deliberately leave home. (...) "And still I could not shake myself free of him".

Powell 280-281, podkr. E.T.)

PL. -Ale nie zawsze było łatwo trzymać się od niego z daleka. (...) W te dni, kiedy odwiedzał domy w jej części wsi, umyślnie wychodziła z domu. (...) - Ale i tak nie zdołałam się od niego uwolnić.

(Tabakowska/Powell 374-375, podkr. E. T.)

Także tym razem tłumacz uznał najwidoczniej, że wierny przekład mógłby urazić polskiego czytelnika. Złagodził „fizyczność” angielskiego zwrotu shake oneself free of („wyrwać się, uwolnić się siłą”, por. „odczepić się”), ale w celu stonowania antyklerykalnej wymowy tego fragmentu zmodyfikował także gramatykę, zmieniając czas teraźniejszy na przeszły i używając anafory w miejsce rzeczownika. W efekcie powstał obraz jednorazowej sytuacji - o mniej silnej wymowie niż ogólne stwierdzenie w oryginale.

Na liście „gorących tematów” KAD Anno Domini 2020 jest też nacjonalistyczna idea „,białej Polski” i „,białej Europy”, z nieodłącznym hasłem „czystej krwi”. Pojawia się związana z masowymi ruchami migracyjnymi ksenofobia i podsycana przez część przekazów medialnych obawa przed ,inwazją uchodźców”. Książka Powell jest książką o emigrantach, o imigrantach i o uchodźcach właśnie. To potencjalny problem dla tłumacza. Na szczęście zarówno językowy kontekst książki, jak i szerokie tło tej narracji, eliminują możliwość

\footnotetext{
5 Potrójny znak zapytania (por. pojedynczy pytajnik w oryginale) został użyty jako odpowiednik zaznaczonego kursywą akcentu wyrazowego (herself) oraz podyktowanego względami kulturowym osłabienia anglojęzycznego wulgaryzmu. Refleksję nad tą przesuwką zawdzięczam jednemu z moich PT Recenzentów.
} 
niedobrych skojarzeń. Rodzice Ireny są uchodźcami w znaczeniu nieobciążonym wymogami aktualnych ideologii. Ani stereotypami, powstającymi w wyniku oddziaływania ideologii.

I jeszcze ostatni, najbardziej wrażliwy (w polskim kontekście) „pod-stereotyp” stereotypu Żyda: antychrześcijanizm, połączony z brakiem tolerancji religijnej; antypolonizm, zarzucany Żydom, mimo że zrodził się $\mathrm{z}$ doświadczeń czasu Zagłady i z politycznego kontekstu późniejszych stosunków polsko-żydowskich. Powstała - i w ciąż powstaje - bogata literatura analizująca ten wątek z różnych perspektyw - nie ma ani potrzeby, ani możliwości, żeby ją w tym miejscu cytować. W kontekście polskiego przekładu książki Powell i jej szerokiego kontekstu warto jednak poruszyć jeszcze jeden aspekt, istotny z punktu widzenia tłumacza: portret Sary, główny cel opowieści Ireny.

Genologiczne przyporządkowanie tekstu, a także antycypacja intertekstualnej wiedzy odbiorców polskiego przekładu, kazałyby umieścić obie protagonistki po stronie ofiar. Ale Sara jest nie tylko ofiarą: po latach, traumatyczna przeszłość młodej Żydówki rzutuje na roszczeniową postawę starej kobiety, walczącej o bezwarunkowe uznanie i miłość, o podziw i bezwzględny szacunek otoczenia. Wyrażając tę postawę wobec swojej brytyjskiej rodziny, Sara bywa nieznośną terrorystką. Sprowadza córkę do roli ofiary aktów agresji, której trudno się bronić przed atakami, ponieważ jej własną traumą są bezustanne wyrzuty sumienia. Czytelnik musi Sarę podziwiać, ale musi ją też znielubić. Czy jednak ma się to stać za sprawą tłumaczki? Sara bywała nieznośna, lubić ją było trudno, ale przecież nie dlatego, że o stosunku do niej decydowały zakorzenione w polskiej kulturze stereotypy.

Stereotypowy Polak ma prawo Sarę znielubić - za wyraz niechęci, albo wręcz pogardy, wobec tchórzostwa „prawdziwego Polaka” (por. (3)) za to, że Polskę kocha i że jej nienawidzi (por. (1)), za jej antyklerykalizm (por. (7)) i za pochwałę „dobrych Niemców” (por. (4)).

Ten brak sympatii nie może jednak stać się skutkiem ujawnienia postaw i emocji thumacza. Jak zatem namalować portret Sary Rubinstein vel Janickiej na tle aktualnego społecznego dyskursu? Odpowiedź na to pytanie jest nieuchronnie subiektywna i można ją zapewne rozszerzyć - mutatis mutandis - na inne studia innych przypadków. Jak powiedzieliśmy, każda konkretna decyzja, każdy wybór, jest osobistą własnością tłumacza. Ostatecznym celem jest obiektywizm, którego jednak z definicji nie da się osiągnąć. Nie da się narysować szczegółowej „mapy drogowej”.

Ogólne zalecenie okaże się więc zapewne po prostu ogólnikowe: tłumacząc książkę Ireny, polska tłumaczka musi się starać uwolnić od niebezpieczeństwa ulegania wpływom toczącego się wokół niej dyskursu. Na przykład od postawy definiowanej jako polski „kolektywny narcyzm, powiązany (...) z obawami o wizerunek własnej grupy, zagrożony oskarżeniami o 
antysemityzm i współudział w prześladowaniach Żydów. Reakcja „,co inni o nas powiedzą” przeważa nad żalem, współczuciem i wstydem” (Lipowska-Teutsch 2016: 133). A także, oddając cudze emocje, musi próbować nie ujawniać własnych.

\section{Wnioski}

Lektura prac poświęconych powiązaniom między przekładoznawstwem i krytyczną analizą dyskursu na ogół skupia się, jak powiedzieliśmy wyżej, na analizie tekstów par excellence politycznych, a konkretne eksplikacje dotyczą zjawisk z zakresu semantyki leksykalnej. Wiedziane $\mathrm{w}$ tej perspektywie, powyższe rozważania nie są oczywiście niczym nowym. Pewne novum stanowi jednak wskazanie na rolę, jaką w kształtowaniu intertekstualnych i interdyskursywnych powiązań odgrywa gramatyczna struktura przekazu. Proponowany w ramach językoznawstwa kognitywnego model gramatyki, oparty na założeniu, że gramatyka symbolizuje treść, otwiera przed analizą przekładu atrakcyjne perspektywy. Zwłaszcza, jeśli podstawą tej analizy stają się zasady i metody wypracowane w ramach krytycznej analizy dyskursu.

Tekst - dyskurs - będący podstawą przedstawionego wyżej studium przypadku skupia jak w soczewce problemy, które najczęściej bywają trudno uchwytne i rozproszone. Z drugiej strony, pozwala rozszerzyć pole badawcze, dostarczając przykładu, który nie jest ani „polityczny”, ani „,ideologiczny”. Zarysowane wyżej problemy mogą mieć także mniej oczywiste konteksty i rozwiązania. Uzasadniają przekonanie, że tłumacz musi zająć stanowisko wobec toczącego się w przestrzeni społecznej dyskursu (lub dyskursów) związanych z tematyką tekstu, nad którym pracuje. Jako uczestnik procesu komunikacji społecznej ma oczywiście prawo do własnego zdania, ale ma też obowiązek starannie ważyć translatorskie interwencje. KAD pomoże mu je odkryć i uzasadnić, potwierdzając tezę Mony Baker, która piętnaście lat temu pisała, że „tłumacze tekstów pisanych i ustnych moga stosować, i stosują, rozmaite strategie pozwalające podkreślać lub tuszować poszczególne aspekty narracji, w których przekazywaniu pośredniczą - explicite lub implicite” (Baker 2006: 105, thum. E.T.).

Jeden $\mathrm{z}$ recenzentów wcześniejszej wersji niniejszego artykułu dopomina się - co zrozumiałe - o „zestaw konkretnych rekomendacji”. Ale konkretnych rekomendacji po prostu być nie może. Jedyną rekomendacją może być uwrażliwienie tłumacza na potencjalne skutki jego decyzji. Autorowi recenzji zawdzięczam jednak cenną sugestię, aby wskazówki (choćby mało konkretne) sformułować w kategoriach analizy SWOT. Jest to jak wiadomo metoda 
analizy strategicznej stosowana w celu optymalizacji funkcjonowania przedsiębiorstw. Mojemu anonimowemu recenzentowi zawdzięczam ideę jej twórczego rozszerzenia. A więc:

- S(trenghths), czyli mocne strony: uznanie KAD i JK jako pożądanych elementów kompetencji tłumacza pozwala dostrzec nowe aspekty znanych zjawisk oraz docenić znaczenie pozornie nieznaczących drobiazgów (także gramatycznych),

- W(eaknesses), czyli słabe strony: nierozwiązany odwieczny dylemat napięć między obiektywizmem i subiektywizmem, ideologią i tożsamością,

- O(pportunities), czyli szanse: zmiana sposobu myślenia o roli gramatyki w dyskursie i roli dyskursu społecznego $\mathrm{w}$ interpretacji tekstu, potencjalnie prowadząca do wprowadzenia dodatkowych kryteriów oceny przekładu ${ }^{6}$,

- T(hreats), czyli zagrożenia: „nadwidoczność” thumacza, niebezpieczeństwo nadmiernego subiektywizmu i pokusa, aby być eager to please: nikomu się nie narażać.

\section{Podziękowania}

Dziękuję trojgu anonimowym Recenzentom za wnikliwą lekturę i krytyczną analizę wcześniejszej wersji niniejszego artykułu. Mam nadzieję, że ich cenne sugestie i wskazówki pozwoliły mi go ulepszyć. Nie bez znaczenia był fakt (o którym nie informowano PT Recenzentów), że jestem autorem zarówno pomawianego przekładu jak i samego omówienia; dzięki recenzjom dostrzegłam niedostatki swojego tłumaczenia, co jest „wartością dodaną”. Wszelkie błędy i niedociągnięcia - w obu częściach tego projektu - są oczywiście wyłącznie moją winą.

\section{Bibliografia}

Baker, Mona (2006) Translation and Conflict: A Narrative Account. Abington: Routledge.

Balcerzan, Edward (1998) Literatura $z$ literatury: strategie thumaczy. Katowice: Wydawnictwo Naukowe „Śląsk”.

${ }^{6} \mathrm{~W}$ szerszym wymiarze, wyniki KAD mogą być uzasadnieniem powstawania serii translatorskich w rozumieniu Edwarda Balcerzana, który twierdzi, że (literacki) oryginał może być materiałem służącym wielu tłumaczom i prowadzącym do powstania licznych przekładów. (por. Balcerzan 1998: 17 i nn.). Seria przekładów może powstać w wyniku wielu czynników: „starzenia się” jako efekt diachronicznych zmian w języku, zmiany obowiązujących norm językowych, kulturowych i edytorskich, dostępu do nowych informacji, itp. 
Bassnett, Susan (1990) “Introduction. Proust's Grandmother and the Thousand and One Nights". The "Cultural Turn" in Translation Studies." [W:] Susan Bassnett, André Lefevere (red.) Translation, History and Culture . Londyn - Nowy Jork: Pinter; 3 - 14.

Bassnett, Susan (1998) „The Translation Turn in Cultural Studies.” [W:] Susan Bassnett, André Lefevere (red.) Constructing Cultures: Essays on Literary Translation. Clevedon, Philadelphia, Toronto, Sydney, Johannesburg: Multilingual Matters; 123-140.

Biskupska, Kamilla (2014) „Analiza dyskursu i krytyczna analiza dyskursu”. [W:] Marek S. Szczepański, Anna Śliz (red.) Współczesne teorie społeczne $w$ kręgu ujęć paradygmatycznych. Opole: Wydawnictwo Uniwersytetu Opolskiego; 369-388.

Bodnar, Adam (2020) “Antysemityzm problemem medialnego dyskursu w Polsce”. [pobrane z: $\quad$ https://www.rpo.gov.pl/pl/content/antysemityzm-problemem-medialnego-dyskursurpo-pyta-krrit-jak-z-nim-walczy. Data ostatniego dostępu: 14-02-2021].

De Bończa Bukowski, Piotr, Magdalena Heydel (2015) „Polish Translation Studies: Toward a Transdisciplinary Research.” [W:] Andrea Ceccherelli, Lorenzo Costantino, Cristiano Diddi (red.) Translation Theories in the Slavic Countries. Salerno: "Europa Orientalis"; $143-158$.

Dijk van, Teun (2001) "Badania nad dyskursem”. [W:] Teun van Dijk, Grzegorz Grochowski,

Teresa Dobrzyńska (red.) Dyskurs jako struktura i proces. (tłum. G. Grochowski). Warszawa: Wydawnictwo Naukowe PWN; 9 - 44.

Dijk van, Teun (2015) "Critical Discourse Analysis". [W:] Deborah Tannen, Heidi E. Hamilton, Deborah Schiffrin (red.). The Handbook of Discourse Analysis. Hoboken, New Jersey: John Wiley \& Sons, Inc.; 466-485.

Duszak, Anna, Norman Fairclough (red.) (2008) Krytyczna analiza dyskursu: interdyscyplinarne podejście do komunikacji społecznej. Kraków: Universitas.

Fairclough, Norman (1985) "Critical and Descriptive Goals in Discourse Analysis". Journal of Pragmatics 9: 739-763.

Fowler, Roger ([1996] 2003) “On Critical Linguistics.” [W:] Carmen-Rosa Caldas-Coulthard, Malcolm Coulthard (red.) Readings In Critical Discourse Analysis. Londyn, Nowy Jork: Routledge; 3-14.

Greene, Richard Allen (2018) "A Shadow over Europe" - raport CNN [pobrane z: https://edition.cnn.com/interactive/2018/11/europe/antisemitism-poll-2018-intl/. Data ostatniego dostępu: 14-02-2021].

Heydel, Magdalena (2013) „Kultura - interwencja - dialog. Tendencje w nowszych studiach nad przekładem”. Fragile 3 (21) 2013; 5-9. 
Ietcu-Fairclough, Isabela (2008) "Critical Discourse Analysis and Translation Studies: Translation, Rexcontextualization, Ideology." Bucharest Working Papers in Linguistics $2 ; 6-73$.

Jurek, Krzysztof (2019) „Stereotypy na temat Ukraińców funkcjonujące w Polsce”. [W:] Imigranci z Ukrainy w Polsce. Potrzeby i oczekiwania, reakcje społeczne, wzywania dla bezpieczeństwa. Wrocław: AWL. [pobrano z: https://www.researchgate.net/publication 1336927733Stereotypy na temat Ukraincow funkcjonujace w Polsce. Data ostatniego dostępu: 10-06-2021].

Kopińska, Violetta (2016) „Krytyczna analiza dyskursu - podstawowe założenia, implikacje, zastosowanie”. Rocznik Andragogiczny 23; 311-334.

Lakoff, George (1989) The Invariance Hypothesis: Do Metaphors Preserve Cognitive Topology? Duisburg: L.A.U.D./A266.

Langacker, Ronald W. (1987) Foundations of Cognitive Grammar. Vol. I. Theoretical Prerequisites. Stanford: Stanford University Press.

Langacker, Ronald W. (2009) Gramatyka kognitywna. Wprowadzenie. (tłum. zespół). Kraków: Universitas.

Libura, Agnieszka (2010) Teoria przestrzeni mentalnych i integracji pojęciowej: struktura modelu i jego funkcjonalność. Wrocław: Wydawnictwo Uniwersytetu Wrocławskiego.

Lipowska-Teutsch, Anna (2016) „Pochwała myślenia krytycznego.” [W:] Antysemityzm nie jest pogladem. Podręcznik dla edukatorów i edukatorek. Kraków: Żydowskie Stowarzyszenie Czulent; 115-140.

Markowski, Michał Paweł (2014) „Obcość, odmienność, przekład”. Tygodnik Powszechny 19-05-2014. [pobrano z: https://www.tygodnikpowszechny.pl/obcosc-odmiennoscprzeklad-22897. Data ostatniego dostępu: 14-02-2021].

Nicolescu, Basarab (2002) Manifesto of Transdisciplinarity (tłum. ang. Karen-Claire Voss) Nowy Jork: State University of New York (SUNY) Press.

Schaeffner, Christina (2004) "Political Discourse Analysis From the Point of View of Translation Studies.” Journal of Language and Politics 3 (1); 117-150.

Shabhazi, Misagh, Mehrdad Rezaee (2017) "Reflection of Ideology on Translation: A Critical Discourse Analysis Perspective.” Journal of Applied Linguistics and Language Learning $3(4) ; 97-101$.

Turski, Marian (2020) “Auschwitz nie spadło z nieba". Polityka 27-01-2020. [pobrano z: https://www.polityka.pl/tygodnikpolityka/kraj/1940080,1,marian-turski-auschwitz-niespadlo-z-nieba.read. Data ostatniego dostępu: 08-05-2021]. 
Warzecha, Adam (2014) „Krytyczna analiza dyskursu (KAD) w ujęciu Normana Fairclougha. Zarys problematyki”. Konteksty Kultury 2; 164-189.

Zhang, Meifang Jeremy Munday (2018) „Innovation in Discourse Analytic Approaches to Translation Studies.” Perspectives 26 (2); 159-165.

\section{Źródła przykładów:}

Powell, Irena (2016) The Daughter Who Sold Her Mother. A Biographical Memoir. Bloomington, IN: AuthorHousde.

Powell Irena (2020) Córka, która sprzedała matkę. (tłum. Elzbieta Tabakowska). KrakówSyrakuzy: Austeria. 